\title{
Utjecaj depopulacije na kulturnu baštinu hrvatskih otoka
}

DOI: $10.11567 /$ met.29.3.4 UDK: 314.87:008](497.5)(210.7)

Pregledni rad

Primljeno: 16.12.2013. Prihvaćeno: 23.1.2014.

\section{Josip Faričić}

Odjel za geografiju, Sveučilište u Zadru, Zadar

jfaricic@unizd.hr

\section{Lena Mirošević}

Odjel za geografiju, Sveučilište u Zadru, Zadar Imirosev@unizd.hr

\section{Vera Graovac Matassi}

Odjel za geografiju, Sveučilište u Zadru, Zadar vgraovac@unizd.hr

\section{SAŽETAK}

U radu se razmatra utjecaj depopulacije na kulturnu baštinu hrvatskih otoka. Višegodišnjim istraživanjem relevantnih statističkih podataka, proučavanjem postojeće literature, arhivskim i terenskim istraživanjem hrvatskih otoka utvrđeno je da je depopulacija najvažniji demografski proces na većini hrvatskih otoka. Smanjenje broja stanovnika ujedno znači smanjenje broja nositelja otočnog identiteta, odnosno različitih sastavnica materijalne i nematerijalne kulturne baštine. Budući da je na otocima sve manje stanovnika mlađe dobi (uz koje se vezuju biološka vitalnost i ekonomska održivost) te da je mlađe stanovništvo snažno zahvaćeno tercijarizacijom gospodarstva i modernizacijom cjelokupnoga života, smanjuje se mogućnost međugeneracijskoga prijenosa tradicionalne otočne kulture. To se posebno odnosi na nematerijalnu kulturnu baštinu poput jezika (bogatog leksika uključujući mnoštvo toponima), glazbe (pučko glagoljaško pjevanje i dr.), vještina (u izradi ribarskih i poljoprivrednih alata i sl.), običajâ i dr. Pritom valja istaknuti da se u suvremenom vrednovanju otočnog prostora, ponajprije putem turizma, pojedini elementi kulturne baštine uglavnom doživljavaju kao kulturne okamine vrijedne prigodnoga interesa, premda upravo kulturni turizam može pridonijeti predstavljanju i zaštiti te optimalnoj gospodarskoj upotrebi otočne kulturne baštine.

KLJUČNE RIJEČI: hrvatski otoci, stanovništvo, depopulacija, kulturna baština 


\section{UVOD}

Stanovništvo je ključni čimbenik svakoga, pa tako i hrvatskoga otočnog prostora (Lajić, 1992, 1997, 2006; Lajić i Mišetić, 2006; Nejašmić, 1991, 2005, 2008). Utjecaj stanovništva ponajprije se očituje u izgradnji i preobrazbi različitih društveno-gospodarskih struktura i krajolika u trajno naseljenom prostoru, nešto je manje izražen u povremeno naseljenom prostoru, a intenzitet čovjekovih djelatnosti izravno se najmanje odražava u nenaseljenom području, osobito onome koje nije predmet gospodarskog vrednovanja. Među 1246 otočnih jedinica utvrđenih istraživanjem T. Duplančić Leder, T. Ujevića i M. Čale (2004) moguće je razlikovati one koje pripadaju ekumeni, subekumeni i anekumeni. Pritom je službene statističke podatke, kojima su određeni prostorni obuhvat i kvantitativna obilježja otočne ekumene, potrebno korelirati s rezultatima terenskih i arhivskih istraživanja. Primjerice po podacima Državnoga zavoda za statistiku Kornatski otoci čine dio ekumene (i na njima se u posljednja dva međupopisna razdoblja broj stanovnika povećao?!), a zapravo su povremeno nastanjeni prostor (subekumena), dok otok Škarda nije dio ekumene, a također je povremeno nastanjeni prostor. S druge strane, otočić Babac u Pašmanskom kanalu statistički nije dio ekumene, premda na njemu zapravo stalno živi nekoliko stanovnika koji imaju osobne iskaznice s adresom na tom otočiću, a u susjednom Turnju na kopnenoj obali (kojemu administrativno pripadaju) čak imaju svoju posebnu biračku jedinicu. Očito je da Babac stoga nije dio anekumene, nego ekumene (Faričić, 2012).

S obzirom na presudni utjecaj čovjeka na različite prostorne strukture, procese, međuodnose te na njihovu prostornu organizaciju posve je logično da demografsko stanje i procesi umnogome definiraju osnovna geografska obilježja hrvatskih otoka, pa tako i kulturu. Kultura se definira na različite načine (čak se i riječ kultura u semantičkom smislu smatra jednom od najkompliciranijih riječi) i u tome mnoštvu definicija mogu se tek istaknuti neke zajedničke odrednice svake kulture: kultura obuhvaća dinamičnu, kompleksnu cjelinu, način života te sveobuhvatnost čovjekova djelovanja u društvu i simboličku komunikaciju grupe ljudi. Kulturu je moguće razmatrati na različite načine ovisno o znanstvenom pristupu (Jackson, 1994), a s geografskog motrišta nastoje se otkriti veze ljudi i njihove okoline preko prihvaćanja kulture kao odrednice tog odnosa (Šakaja, 1997). Kultura je usto intersubjektivna stvarnost (Richardson, 1981, prema Šakaja, 1999). Podrazumijeva stanje u kojem veliku ulogu u međuljudskoj komunikaciji imaju simboli koje treba objašnjavati u kontekstu njihova funkcioniranja $u$ 
društvenoj grupi u kojoj pojedinac živi i djeluje. Kako pišu J. Chevalier i A. Gheerbrant u Rječniku simbola (2007), nije dostatno reći da živimo u svijetu simbola - svijet simbola živi u nama.

O kulturi hrvatskoga otočnog prostora u tom kontekstu moguće je raspravljati na različite načine i s različitih motrišta. Bibliografija o kulturnoj baštini na hrvatskim otocima obuhvaća stotine znanstvenih radova i drugih publikacija. Među tim publikacijama ističu se multidisciplinarne znanstvene monografije i zbornici radova o pojedinim otocima, pri čemu je redovito obrađena i kulturna baština. Od tih knjiga u novije vrijeme sveobuhvatnošću prikaza kulturne baštine ističu se one o Žirju (1994), Drveniku (2000), Ravi (2008), Istu i Škardi (2010), Rabu (2012), Šolti (2012), Silbi (2013) i Velom Ratu na Dugom otoku (2013). Posebno valja istaknuti i toponimijske monografije o Pašmanu (2006), Ugljanu (2007), Vrgadi (2009), Murteru (2010), Pagu (2011) i Kornatima (2013) u kojima je iscrpno razmotrena jezična baština, ali i kulturno-geografski ambijent u kojima su se toponimi oblikovali i upotrebljavali. O graditeljskoj baštini i drugim pokretnim i nepokretnim likovnim ostvarenjima, kulturnom krajoliku, glazbenoj baštini, književnosti, jezičnoj baštini, narodnim nošnjama te tradicionalnim obrtima i običajima na hrvatskim otocima pisali su brojni povjesničari umjetnosti, jezikoslovci, povjesničari, etnolozi, kulturni antropolozi, geografi, sociolozi i dr. i teško je objektivno odabrati i kritički ukratko analizirati doprinos najrelevantnijih znanstvenih rezultata iz različitih područja znanosti. S geografskog motrišta, s kojega se pristupa analizi odnosa depopulacije i kulturne baštine u ovom radu, zacijelo su najvažnija ona istraživanja u kojima je naglašen prostorni diskurs, pri čemu se u istraživanju kulturne baštine ističe prostorna varijabla kao ona u kojoj se zbiva razvoj kulture i u kojoj se pojedine sastavnice kulturne baštine vrednuju. U tom pogledu valja istaknuti radove u kojima se, općenito, kulturna baština u Hrvatskoj vrednuje u sklopu turizma i drugih gospodarskih djelatnosti, o čemu su s etnološkoga i kulturno-antropološkog motrišta pisali D. A. Jelinčić (2006) te V. Klarić i J. Vince Pallua (2006), a s ekonomskoga T. Pančić Kombol (2006), V. Vrtiprah (2006) i T. Gredičak (2009). Vrijedan je prilog proučavanju kulturne baštine i njezina značenja za identitet arhivista M. Vukovića (2011). Odnos stanovništva i kulturne baštine na hrvatskim otocima do sada su razmatrali jezikoslovac V. Skračić (1997), sociolog I. Lajić (2000) i geograf J. Faričić (2007). $\mathrm{K}$ tome, V. Skračić razmatrao je esejistički, ali na temelju višedesetljetnih sustavnih znanstvenih istraživanja, značenje kulturne baštine za identitet hrvatskih otoka (Skračić, 2008, 2013). 
Predmet istraživanja koje je rezultiralo ovim radom jest utjecaj depopulacije na kulturnu baštinu hrvatskih otoka. Rezultati višegodišnjeg istraživanja temelje se na obradi relevantnih statističkih podataka, proučavanju postojeće znanstvene literature te arhivskom i terenskom istraživanju hrvatskih otoka. Tako su dobiveni podaci koji su korelirani, što je omogućilo njihovu usporednu analizu te putem indukcije donošenje odgovarajućih zaključaka. Istraživanje je počelo oblikovanjem hipoteze da je depopulacija ključni demografski proces koji izravno utječe na kulturnu baštinu jer se smanjenjem broja stanovnika na hrvatskim otocima smanjuje i broj nositelja tradicionalne kulture te onih koji in situ, u svakidašnjem životu, oblikuju kulturu ili vrednuju postojeće elemente kulturne baštine, nerijetko stare više stoljeća. Cilj je istraživanja, s geografskog motrišta, dati pregled posljedica utjecaja depopulacije na različite sastavnice kulturne baštine, koja se po UNESCO-ovoj klasifikaciji dijeli na materijalnu te nematerijalnu baštinu (engl. intangible heritage). Materijalnu baštinu čine različita pokretna i nepokretna ostvarenja na polju graditeljstva, likovne, glazbene i scenske umjetnosti, književnosti i drugih oblika kulturnoga izražavanja te znanstvena postignuća s povijesnom, estetskom, etnološkom i antropološkom vrijednošću (Convention concerning the Protection of the World Cultural and Natural Heritage, 1972), dok nematerijalnu baštinu čine usmene tradicije i izrazi, uključujući jezik kao sredstvo nematerijalne kulturne baštine, ostvarenja različitih izvedbenih umjetnosti, društveni običaji, rituali i svečanosti, znanja i prakse vezane uz prirodu i svemir te tradicionalni obrti (Convention for the Safeguarding of Intangible Cultural Heritage, 2003). Iz tih je pojednostavljenih definicija posve razvidno da bitno značenje kulture proizlazi iz činjenice da je ona značajka različitih aspekata ljudskoga života i djelovanja. "Sva se ljudska aktivnost odvija unutar neke kulture i u interakciji s njom ", kaže papa Ivan Pavao II. u enciklici Centesimus Annus (1991).

Hrvatski otoci prostor su gdje je stoljećima u okvirima različitih etničkih, političkih, ekonomskih, vjerskih i jezičnih zajednica oblikovana raznovrsna kulturna baština, od one koja je povezana sa svakidašnjicom, u kojoj se izmjenjivao dnevni i godišnji ritam različitih aktivnosti povezanih ponajviše s poljoprivredom i pomorstvom, do one koja je rezultirala vrhunskim umjetničkim ostvarenjima nadahnutim umnogome prirodom, životnim radostima i poteškoćama te kršćanstvom (Faričić, 2007). Pritom valja istaknuti da je baština suvremena upotreba prošlosti, odnosno više verzija prošlosti konstruiranih u suvremenim kontekstima. Na taj se način značenje baštine definira u sadašnjosti ponajprije u svrhe odgoja i obrazovanja, ali i gospo- 
darskog razvoja, najčešće putem turizma, pri čemu može doći do banalizacije, tj. do pretvaranja kulture u robu i predmet potrošnje (Atkinson, 2008).

U kulturi se prožimaju materijalni i duhovni dijelovi iste cjeline svakoga pojedinca i društva u kojemu taj pojedinac djeluje. Pritom je »prostor materijalna podloga kulture « (Šakaja, 1999: 42). Štoviše, cijeli prirodni i društveni okoliš u kojem su djelovali otočani su pretvorili u kulturni prostor, koji se može najbolje sagledati putem kulturnoga krajolika. Raznovrsnost i gustoća pojedinih elemenata kulturne baštine ovisile su, uz ostalo, o broju stanovnika, njihovoj komunikaciji sa susjednim otočnim i kopnenim zajednicama te o stupnju društveno-gospodarske razvijenosti. More je služilo kao medij komunikacije putem kojega su ostvarivane višestruke veze sa širim prostorom Sredozemlja, pa su otoci, s dijelovima obalnih regija kojima pripadaju, postali dio sredozemnoga kulturnog areala (Magaš, 2013).

\section{ODNOS DEPOPULACIJE I KULTURNE BAŠTINE NA HRVATSKIM OTOCIMA}

Smanjenje broja stanovnika kao ključni demografski proces na hrvatskim otocima (uz iznimke nekih većih otoka koji imaju porast broja stanovnika) ujedno znači smanjenje broja nositelja otočnog identiteta, odnosno različitih sastavnica materijalne i nematerijalne kulturne baštine. Depopulacija u tom kontekstu pridonosi osiromašenju kulture, premda u gusto naseljenim područjima smanjenje broja stanovnika može imati i pozitivne učinke, primjerice može smanjiti pritisak na pojedine sastavnice kulturne baštine (Lajić, 2000).

Kulturu umnogome obilježava raznolikost, koja oplemenjuje svaku društvenu zajednicu, poput bioraznolikosti, koja obogaćuje svijet prirode (UNESCO Universal Declaration on Cultural Diversity, 2001). Kulturna raznolikost pridonosi intelektualnome, emocionalnome, moralnom i duhovnom ostvarenju čovjeka, a njezinu obranu UNESCO proklamira kao moralni imperativ. Naravno, ta je tematika u UNESCO-u razmatrana globalno, u odnosu na potrebu međunarodne suradnje, odnosno međusobnog uvažavanja svjetskih država, kultura i religija. No u moderno vrijeme višestrukih mogućnosti komunikacije i s njom povezanih kontakata i konflikata globalna je razina isprepletena s lokalnom. Taj globalno-lokalni pleter sve više utječe na uniformiranje i svojevrsnu standardizaciju različitih sastavnica kulture i onih prostora koje je sve donedavno, zahvaljujući perifernosti u odnosu na društveno-gospodarske jezgre, obilježavala svojevrsna perzistentnost tradicionalnoga u odnosu na moderno, bez obzira na to pridaju li se 
tim atribucijama različitih društvenih i gospodarskih aktivnosti pozitivni ili negativni predznaci. Uostalom, u procjeni suvremenoga razvoja teško je davati apsolutne ocjene jer $u$ kontekstu kulture nije uvijek moguće razvoj poistovjetiti s napretkom, iskorakom u bolje u odnosu na prethodno stanje (Šakaja, 1999).

Budući da je zbog depopulacije na otocima sve manje stanovnika mlađe dobi (uz koje se vezuju biološka vitalnost i ekonomska održivost) te da je mlađe stanovništvo snažno zahvaćeno tercijarizacijom gospodarstva i modernizacijom cjelokupnoga života, smanjuje se mogućnost međugeneracijskoga transfera tradicionalne otočne kulture. To se posebno odnosi na nematerijalnu kulturnu baštinu poput jezika (bogatog leksika, uključujući mnoštvo geografskih imena, naziva za biljne i životinjske vrste i geomorfološke oblike), glazbe (pučko glagoljaško pjevanje i dr.), vještina (u izradi ribarskih i poljoprivrednih alata i sl.), običajâ i dr., a dugoročno utječe i na različite materijalne sastavnice kulture (npr. sukcesijom biljnog pokrova na mjestima nekadašnjih maslinika i vinograda nestaju tvorbeni elementi tradicionalnoga agrarnoga krajolika). Na većini hrvatskih otoka, posebno intenzivno na malima i od kopna udaljenima, kulturna baština nepovratno se gubi. Taj gubitak zapravo je u neposrednoj vezi s demografskim gubicima. Depopulacija na hrvatskim otocima može se sagledati i kroz prizmu litoralizacije, koja je u Hrvatskoj obilježena intenzivnim društveno-gospodarskim aktivnostima uz uski obalni rub kopna, ponajviše u obalnim regionalnim središtima (Faričić, 2012). Konvergencija prema gradskim obalnim naseljima kopna u kojima se moglo školovati, zaposliti i uživati brojne druge dobrobiti koje omogućuje moderno društvo (na polju kulture, sporta, zabave i dr.) demografski je ispraznila otoke i zaobalje, koji, pojednostavljeno rečeno, $u$ gospodarskome i društvenom smislu nisu mogli osigurati zahtjeve otočana za boljim životnim standardom. Naravno, iseljavanje s otoka nema uvijek konačno odredište na susjednoj obali. Migracije s hrvatskih otoka još od druge polovine 19. stoljeća završavale su i u najudaljenijim useljeničkim odredištima poput SAD-a, Čilea, Argentine, Australije te zapadnoeuropskih zemalja (Nejašmić, 2008; Čizmić, 1974-1975).

Proučavanjem dinamike depopulacije na hrvatskim otocima moguće je utvrditi nekoliko zakonitosti. S obzirom na veličinu otoka (po površini i broju stanovnika) tom su negativnom demografskom procesu najviše izloženi mali otoci. S obzirom na udaljenost od kopna i, povezano s time, prometnu povezanost $u$ najgorem su položaju udaljeni pučinski otoci i otoci vanjskog niza, a u takvu su položaju s obzirom na regionalnu pripadnost sjevernodalmatinski (uglavnom mali i u prostoru raspršeni) otoci (Faričić, 
Graovac i Čuka, 2010; Graovac, 2004, 2009). Od 1948. do 2011. čak 29 (od ukupno 49) otoka zabilježilo je smanjenje broja stanovnika od $50 \%$ i više, devetnaest otoka zabilježilo je smanjenje od $70 \%$ i više, a na četiri otoka broj stanovnika smanjio se za više od $90 \%$. Palagruža, Škarda i Sv. Andrija posve su depopulirali. Male i Vele Srakane, Susak i Biševo imali su po popisu iz 2011. manje od 10\% stanovnika u odnosu na broj utvrđen 1948., a Unije, Premuda, Olib, Sestrunj, Krapanj, Žirje i Drvenik imali su 2011. manje od $20 \%$ u odnosu na broj stanovnika utvrđen 1948. Na tim je otocima raznolikost kulturne baštine najugroženija. Veliki su razmjeri depopulacije i na brojnim drugim malim hrvatskim otocima (tablica 1).

Osim depopulacije na malim je otocima temeljni demografski proces intenzivno starenje stanovništva, koje se posebice očituje u prosječnoj dobi otočana (Nejašmić, 2013). Iako je prosječna dob stanovništva hrvatskih otoka 2011. bila 45,1 godinu, treba naglasiti da je na pojedinim malim i od kopna udaljenim otocima prosječna dob iznad 60 godina. $S$ druge strane, analiza dobno-spolnog sastava stanovništva jasno pokazuje smanjenje udjela mlađih dobnih skupina te povećanje udjela pripadnika starijih dobnih skupina zrelog stanovništva i starog stanovništva ${ }^{1}$ (slika 1 ). U pojedinim je otočnim sredinama mladog stanovništva izrazito malo ili ga uopće nema. Iz toga je jasno da stariji otočani elemente kulturne baštine nemaju na koga prenijeti.

1 Primjerice 2011. najzastupljenija dobna skupina stanovništva na hrvatskim otocima bila je ona od 60 do 64 godine. 


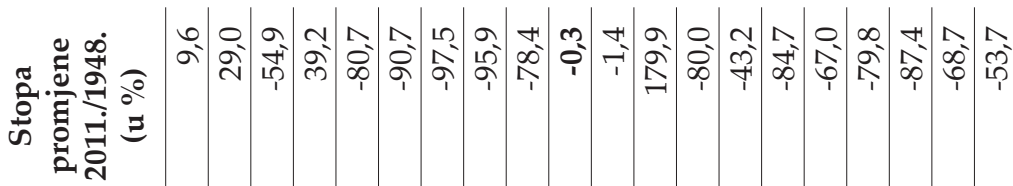

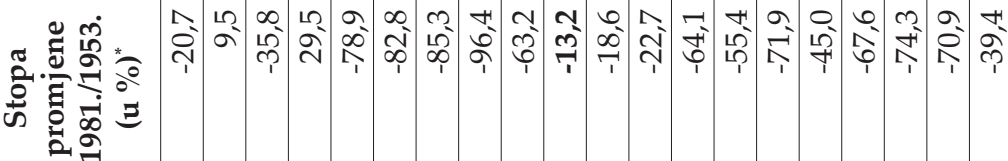

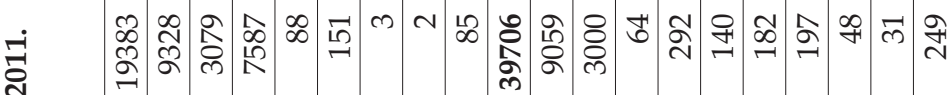

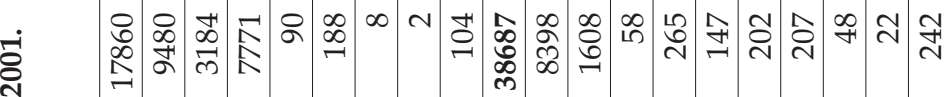

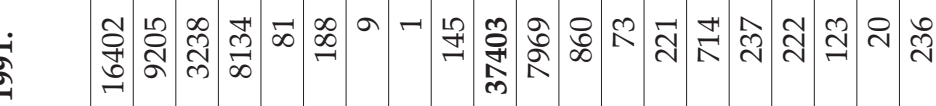

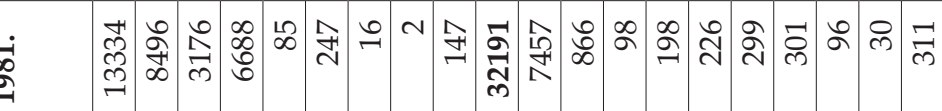

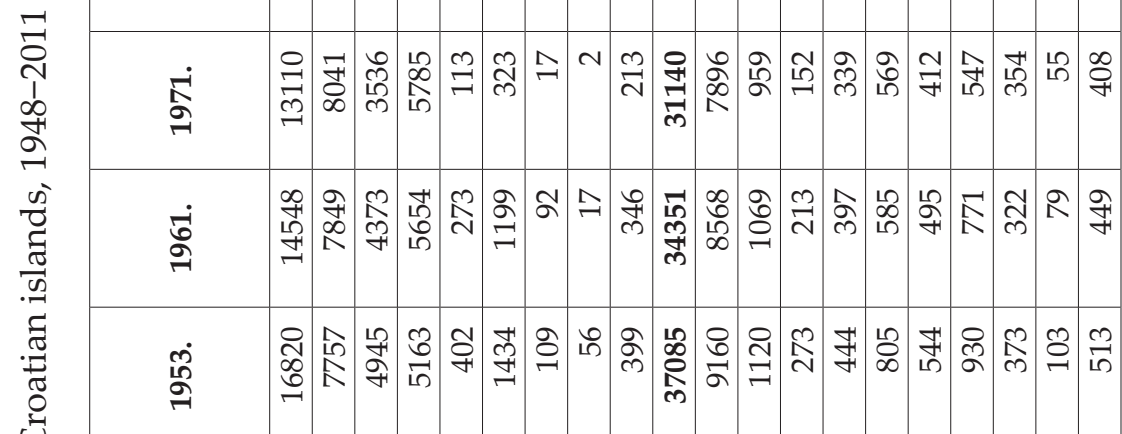
둥

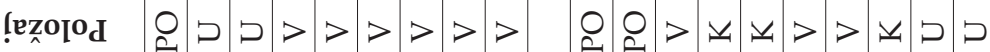




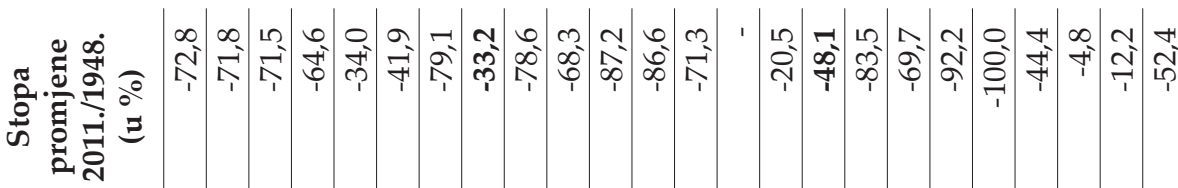

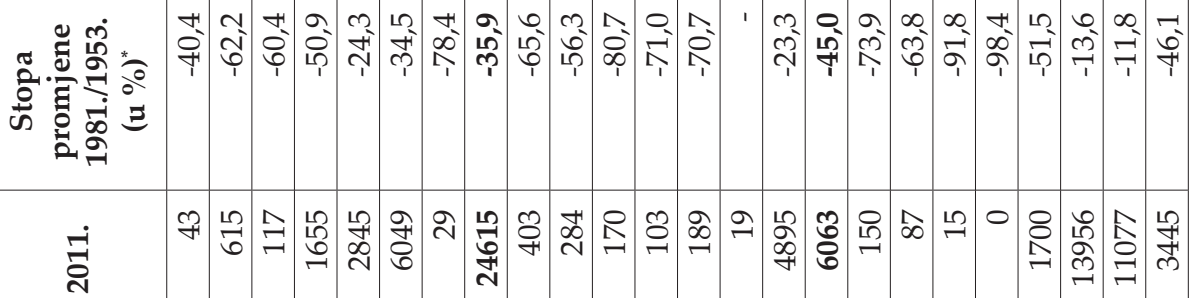

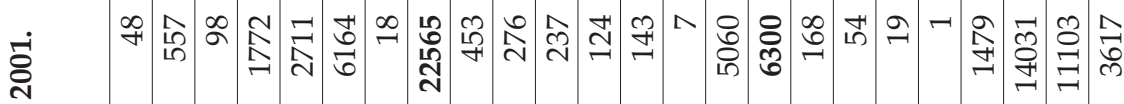

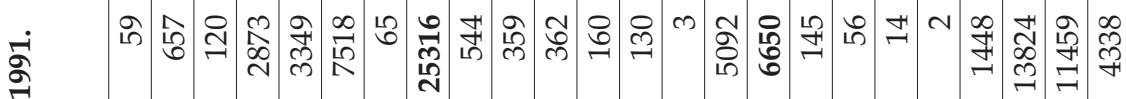
孚

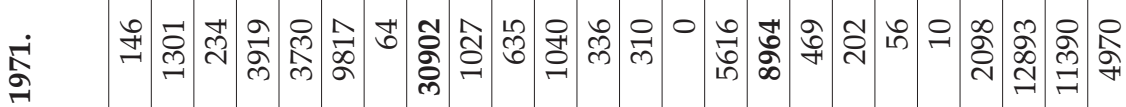

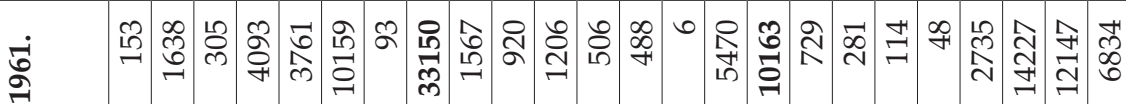

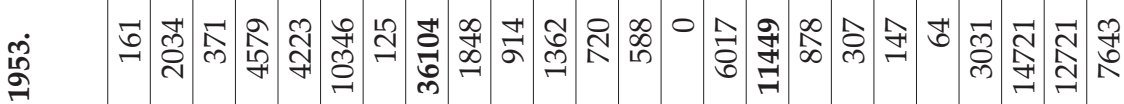

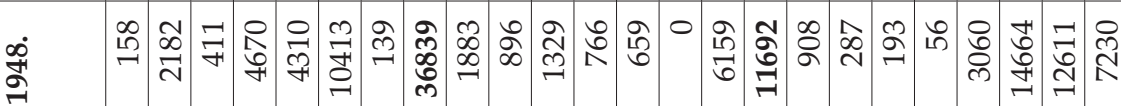

!ezolod

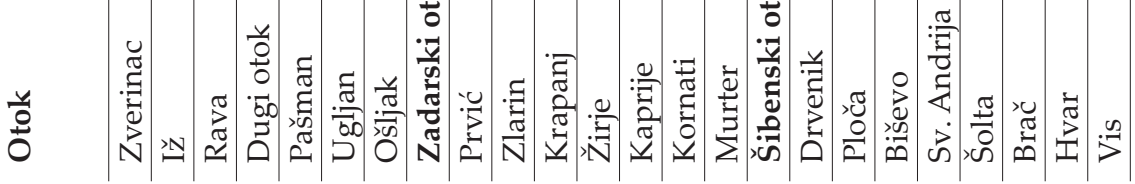




\begin{tabular}{|c|c|c|c|c|c|c|c|c|c|c|c|c|c|c|c|}
\hline 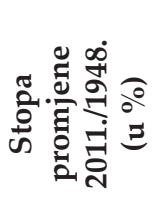 & $\begin{array}{l}0 \\
8 \\
\frac{0}{7}\end{array}$ & $\begin{array}{l}0 \\
8 \\
10 \\
-1\end{array}$ & ำ & $\frac{7}{7}$ & $\begin{array}{ll}1 \\
10 \\
10 \\
1\end{array}$ & c & is & & & & ה: & $\begin{array}{c}0 \\
\infty \\
\rightarrow 1\end{array}$ & 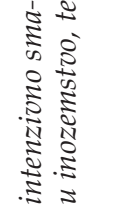 & $\begin{array}{c}1 \\
0 \\
0 \\
0 \\
0 \\
0 \\
0 \\
0 \\
0 \\
0 \\
0 \\
0 \\
0\end{array}$ & 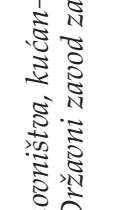 \\
\hline 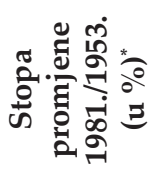 & $\begin{array}{l}0 \\
8 \\
\frac{8}{7}\end{array}$ & $\widehat{尺}$ & $\begin{array}{l}1 \\
\text { के } \\
\text { Tे}\end{array}$ & 둑 & f & ? & 5 & & $\begin{array}{ll}-1 \\
v \\
? \\
?\end{array}$ & S & $\begin{array}{l}\sigma \\
\sigma^{2}\end{array}$ & \begin{tabular}{l}
0 \\
$\stackrel{0}{2}$ \\
\multirow{1}{1}{}
\end{tabular} & 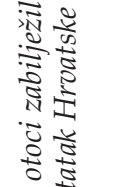 & 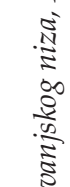 & 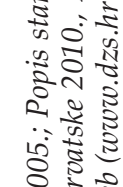 \\
\hline ت्ञ & 0 & $\begin{array}{l}\infty \\
8 \\
8 \\
10\end{array}$ & $\begin{array}{l}\infty \\
\infty \\
\text { రై } \\
\text { లి }\end{array}$ & $\begin{array}{l}\text { สี } \\
\text { เก } \\
\text { ก }\end{array}$ & $\frac{9}{7}$ & $\stackrel{0}{\check{c}}$ & & 8 & D & रे & $\begin{array}{c}\infty \\
\tilde{N} \\
\infty \\
-1\end{array}$ & 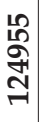 & 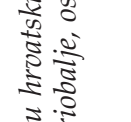 & $\begin{array}{l}\frac{a}{0} \\
0 \\
1 \\
1\end{array}$ & 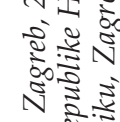 \\
\hline ठ். & 0 & $\begin{array}{l}\infty \\
\infty \\
n \\
10\end{array}$ & $\begin{array}{l}\text { in } \\
\infty \\
10 \\
\text { m }\end{array}$ & $\begin{array}{l}2 \\
\infty \\
6 \\
-1\end{array}$ & भ̊ & व & & 5 & Z & $\begin{array}{l}0 \\
0 \\
0\end{array}$ & ڤ̂̀ & $\begin{array}{l}\infty \\
\underset{Z}{ت} \\
\underset{\sim}{Z}\end{array}$ & 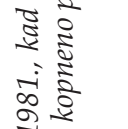 & $\begin{array}{l}\frac{\pi}{0} \\
\frac{\tilde{\pi}}{\frac{\pi}{\pi}} \\
\frac{\pi}{\pi}\end{array}$ & 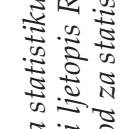 \\
\hline Бें & 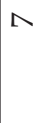 & $\underset{\sim}{\stackrel{F}{m}}$ & 告 & 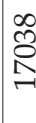 & $\stackrel{8}{\llcorner}$ & $\frac{\alpha}{c}$ & & $\begin{array}{l}0 \\
\text { O } \\
\text { - }\end{array}$ & ב. & $\begin{array}{l}E \\
\text { Z }\end{array}$ & Sू' & 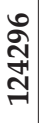 & 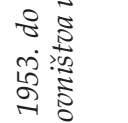 & $\begin{array}{l}1 \\
\text { I } \\
\stackrel{N}{\Xi}\end{array}$ & 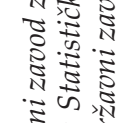 \\
\hline$\stackrel{\infty}{\sigma}$ & 0 & ลิ & 옹 & $\frac{3}{7}$ & L & Á & & \pm & مิ & 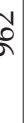 & 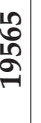 & $\begin{array}{l}\text { సे } \\
\stackrel{\text { ले }}{=}\end{array}$ & 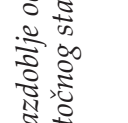 & 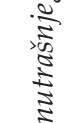 & 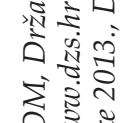 \\
\hline 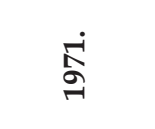 & $\stackrel{m}{\sim}$ & ڤั & సิ & के & $\infty$ & d & & $\vec{v}$ & $\begin{array}{l}0 \\
0 \\
0 \\
\end{array}$ & $\begin{array}{c}2 \\
\\
\end{array}$ & ホั & $\begin{array}{l}\hat{\infty} \\
\stackrel{0}{1} \\
\text { Nิ }\end{array}$ & 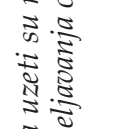 & $\begin{array}{l}\frac{a}{0} \\
0 \\
1 \\
1 \\
2\end{array}$ & 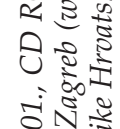 \\
\hline Бें & $\infty$ & กิ & $\begin{array}{l}10 \\
100 \\
\text { ले } \\
\text { ले }\end{array}$ & 9 & $\infty$ & 7 & & P & 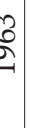 & E & 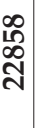 & 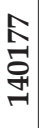 & 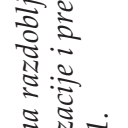 & $\frac{\sqrt{2}}{\frac{2}{2}}$ & 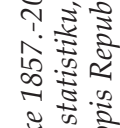 \\
\hline ஜू் & 象 & 亲 & $\frac{\hat{2}}{2}$ & वे & L্ & 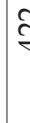 & & $\begin{array}{c}\hat{V} \\
\end{array}$ & 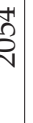 & הี & స̃ & 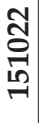 & 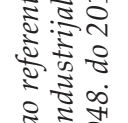 & $\begin{array}{l}\vec{w} \\
\stackrel{5}{\vdots} \\
\vdots \\
\vdots\end{array}$ & 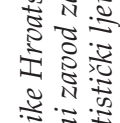 \\
\hline$\stackrel{\infty}{\stackrel{\infty}{\sigma}}$ & 6 & 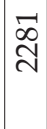 & ัำ & $\begin{array}{l}0 \\
10 \\
\infty \\
1 \\
-1\end{array}$ & 吉 & d & & $\vec{v}$ & 总 & $\underbrace{\infty}$ & $\begin{array}{l}\text { ڤ్ } \\
\text { ลิ } \\
\text { ลे }\end{array}$ & $\begin{array}{l}\text { ลิ } \\
\text { సิ } \\
\text { ถิ? }\end{array}$ & 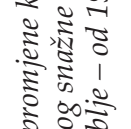 & 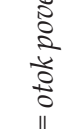 & 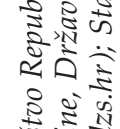 \\
\hline lezolodod & a & 0 & & $\square$ & 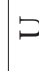 & 2 & & D. & D & 2 & & & $\frac{0}{0} \frac{0}{5}$ & $\begin{array}{l}0 \\
0 \\
0 \\
0\end{array}$ & 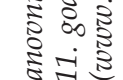 \\
\hline $\begin{array}{l}\text { 능 } \\
\text { பे }\end{array}$ & 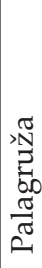 & ن & 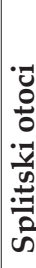 & $\frac{\pi}{3}$ & ฮิ & & & है & 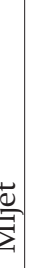 & $\begin{array}{l}0 \\
0 \\
0 \\
0\end{array}$ & 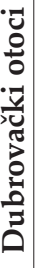 & 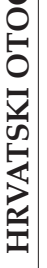 & 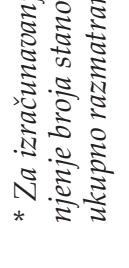 & $\begin{array}{l}0 \\
0 \\
1 \\
0 \\
0 \\
0 \\
3 \\
2 \\
2 \\
0 \\
0 \\
0\end{array}$ & 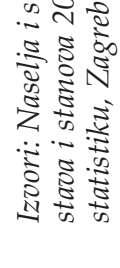 \\
\hline
\end{tabular}




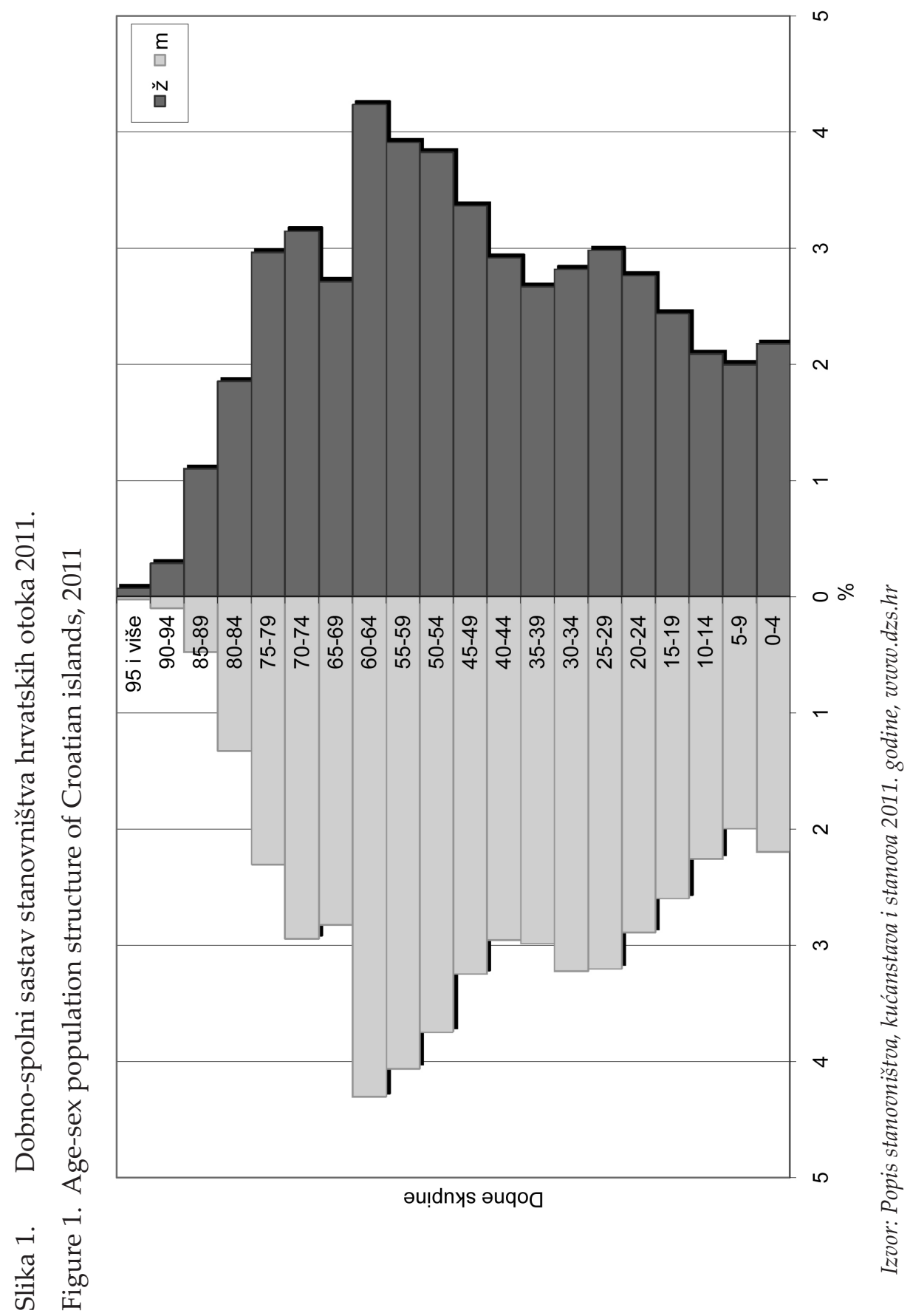


Depopulacija ima najmanje razmjere na velikim i prometno dobro povezanim otocima, odnosno na pseudootocima, koji su s kopnom povezani mostom, i na otocima unutrašnjeg niza, koji imaju česte i brze veze sa susjednim kopnom (tablica 1). Po popisnim podacima, $\mathrm{u}$ razdoblju poslije Drugoga svjetskoga rata (1948. - 2011.) Krk, Vir i Čiovo imali su značajni porast broja stanovnika (premošteni otoci), a porast je zabilježen i na Rabu i Lošinju. Na tim kao i na velikim dalmatinskim otocima na kojima je depopulacija zabilježena, ali nije intenzivna (Pag, Brač, Hvar i Korčula) više je nositelja ili neposrednih dionika očuvanja postojećega kulturnog identiteta. Na svim su velikim hrvatskim otocima ujedno i bogatiji institucionalni oblici kulturnih aktivnosti s obzirom na veliki broj različitih kulturnih ustanova (muzeji, galerije, zbirke, centri za kulturu, knjižnice, čitaonice i dr.) i kulturnih udruga, i to svjetovnih i onih koje su vezane uz pojedine crkvene ustanove (primjerice biskupije sa sjedištima u Krku i Hvaru te veći samostani na Krku, Rabu, Hvaru i Braču). S tim je povezan i veći broj različitih kulturnih manifestacija koje nadilaze otočne, pa i regionalne okvire, poput Osorskih glazbenih večeri, Rapske fjere, Paškoga kulturnog ljeta, Hvarskih ljetnih priredbi i dr. U tom su kontekstu znakoviti rezultati istraživanja koje su na Ugljanu, Ižu i Dugom otoku proveli D. Babić, I. Lajić i S. Podgorelec (2004). Zbog činjenice da je kulturni život na tim zadarskim otocima razmjerno siromašan, mladi stanovnici nedostatak kulturnih sadržaja smatraju jednim od važnih razloga za preseljenje na kopno, a kulturni i zabavni sadržaji važan su motiv dnevne i tjedne cirkulacije otočnoga stanovništva na relaciji otok - kopno (u konkretnom slučaj Zadar).

Važno je istaknuti da se u suvremenom vrednovanju otočnog prostora, ponajprije putem turizma, pojedini elementi kulturne baštine uglavnom doživljavaju kao kulturne okamine vrijedne prigodnoga interesa. To je dijelom posljedica činjenice da se brojni elementi kulturne baštine takvima uopće ne doživljavaju (npr. različite vještine vezane uz tradicionalne gospodarske djelatnosti poput izgradnje drvenih brodica, pletenja košara i ribarskih alata od pruća sredozemnoga grmolikog bilja) ili ih se čak sustavno potiskuje (npr. lokalni govori gube se pod utjecajem spontane i, što je gore, prisilne jezične standardizacije u pogledu leksika, sintakse i akcentuacije u školstvu, medijima, službenim dokumentima i dr.). Istodobno se kao kulturna baština najčešće percipira samo ono što je estetski privlačno ili monumentalno, primjerice sakralno graditeljstvo (od ostataka starokršćanske arhitekture i srednjovjekovnih crkvica do samostanskih i katedralnih kompleksa) i drugi oblici umjetničkog izražavanja vezani uz različite svjetovne i religijske sadržaje, poput čipkarstva na Pagu i Hvaru te procesije Za Križen na otoku Hva- 
ru koji su uvršteni na UNESCO-ovu Reprezentativnu listu nematerijalne kulturne baštine čovječanstva. Inače, kulturno dobro nacionalnog značenja u Hrvatskoj se administrativno utvrđuje (rješenjem Ministarstva kulture) na temelju stručnog vrednovanja i prijedloga stručnog povjerenstva. $\mathrm{Na}$ nacionalnoj listi zaštićene kulturne baštine nalaze se mnoga nepokretna i pokretna kulturna dobra te nematerijalna kulturna dobra s hrvatskih oto$\mathrm{ka},{ }^{\oplus}$ a za mnoga dobra priprema se dokumentacija koju tek treba evaluirati. To znači da se kulturnoj baštini u posljednje vrijeme pristupa sustavno i znanstveno utemeljeno, što je svakako važan iskorak u njezinu očuvanju, proučavanju i primjerenom predstavljanju javnosti. Sukladno tome sve je kvalitetnije vrednovanje kulturne baštine u turizmu, što pridonosi obogaćivanju turističke ponude na otocima, a posebno razvoju kulturnog turizma (Jelinčić, 2006; Pančić Kombol, 2006; Vrtiprah, 2006). To je posebno važno jer je na velikom broju hrvatskih otoka turizam jezgra gospodarskih aktivnosti.

\section{ODABRANI PRIMJERI IŠČEZAVANJA KULTURNE BAŠTINE}

Prikaz i analiza svih sastavnica kulturne baštine zahtijevali bi cijelu monografiju, osobito kada bi se kao temelj istraživanja obuhvatili svi relevantni kulturni indikatori. Stoga će se na odabranim primjerima pokazati kako depopulacija i s njom povezan nepovoljni demografski sastav stanovništva utječu na iščezavanje kulturne baštine. To su kulturni krajolik, jezična baština i vještine vezane uz tradicionalne obrte. Oni su zbog smanjenja broja autohtonog stanovništva, ali i promjene načina života povezane s modernizacijom uvođenjem tehnoloških inovacija i prihvaćanjem elemenata urbanizacije te sa strukturnim gospodarskim promjenama (istodobnim procesima deagrarizacije i tercijarizacije) najizloženiji preobrazbi ili nestanku. U istim okolnostima društveno-gospodarskog razvoja hrvatskih otoka materijalnu baštinu lakše je sačuvati te muzeološki i konzervatorski zaštititi. To se i radi $\mathrm{u}$ različitim kulturnim ustanovama na većim otocima (npr. na Cresu, Krku, Lošinju, Rabu, Pagu, Hvaru, Korčuli, Visu i dr.), rjeđe i na pojedinim manjim otocima (na Ižu, Zlarinu i Krapnju), a veliki dio pokretne kulturne baštine (osobito različitih umjetnina) koja je nastala ili je dugo upotrebljavana na hrvatskim otocima čuva se u muzejima u vodećim hrvatskim kulturnim središtima.

Stanovnici hrvatskih otoka poljoprivrednim su iskorištavanjem tla i tradicionalnim gospodarenjem ostalim prirodnim resursima stvarali kulturni krajolik koji kao cjelina čini iznimno važni dio kulturne baštine. UNESCO 
izrijekom definira kulturni krajolik kao zajedničko djelo čovjeka i prirode te ilustrira razvoj ljudske zajednice i njezine prostorne okoline tijekom vremena, pod vanjskim i unutarnjim utjecajem fizičkih ograničenja i mogućnosti koje su određene njezinom prirodnom okolinom pod utjecajem društvenih, gospodarskih i ostalih poticaja (Convention concerning the Protection of the World Cultural and Natural Heritage, 1972). Sukladno depopulaciji kulturni krajolik intenzivno se mijenja. Oblikuje se tzv. depopulacijski krajolik (Lajić, 2000) s napuštenim dijelovima otočnih naselja (osobito onih podalje od mora), zapuštenim maslinicima i vinogradima i dr. Tome pridonosi najprije deagrarizacija, koja je rezultat ciljanoga napuštanja poljoprivrede radi preorijentacije stanovništva na profitabilniju ili lakšu gospodarsku djelatnost. No danas, kada je radno aktivnoga stanovništva na otocima ionako vrlo malo, preostalo starije stanovništvo više ne može obrađivati zemlju, pa, premda nevoljko, postupno napušta poljoprivredu. Napuštaju se najprije udaljenije čestice te one koje nisu dostupne zbog zarastanja lokalne prometne kapilarne infrastrukture (usp. Faričić, Čuka i Colić, 2010; Čuka, 2013; Jović Mazalin, 2014). Na nestanak tradicionalnih elemenata kulturnoga krajolika utječu i prenamjena poljoprivredne zone u građevinsku te ilegalna izgradnja na obali najbližim dijelovima nekadašnjega poljoprivrednog zemljišta. Kulturni krajolik nestaje pod vegetacijom koja buja na nekadašnjim maslinicima i vinogradima, pa čak i okućnicama, te pod građevinama koje dimenzijama, oblikom, upotrijebljenim materijalima i bojom odudaraju od tradicionalnoga graditeljstva. Nestaje mozaik suhozida (suhozidi zarastaju ili se urušavaju pod utjecajem vegetacije, uklanjaju se radi izgradnje infrastrukture i dr.), a krajolik terasa pod maslinicama i vinogradima te pašnjački krajolik (velike bioraznolikosti!) ustupa mjesto krajoliku izvorne mediteranske makije i šume, vrlo često i krajoliku šuma alepskog bora, alohtone i invazivne vrste, te na brojnim, posebno većim i kopnu bližim otocima krajoliku apartmanskih naselja, pri čemu je Vir možda najpoznatiji, ali, nažalost, ne i jedini primjer. Uz apartmanska naselja kao zasebne graditeljske entitete česte su i interpolacije $u$ postojećim otočnim urbanim i ruralnim naseljima te $u$ poljoprivrednom području koje u pogledu fizionomije i veza s otočnim prostornim sustavom, čak i u rijetkim slučajevima kad su arhitektonski osmišljene, funkcioniraju kao posve neovisne i otocima strane tvorevine.

U tom pogledu hrvatski otoci nisu nikakva posebnost jer je problem nestajanja i devastacije tradicionalnih ruralnih krajolika prisutan u čitavoj Europi, osobito na Sredozemlju. Brojni primjeri u Španjolskoj, Grčkoj, Italiji i Portugalu (Fernandez Ales i dr., 1992; Gams i dr., 1993; Kizos i Koulouri, 2006; Arianoutsou, 2001; Pungetti, 1995; Pinto-Correia i Vos, 2004) pokazuju 
slične procese napuštanja poljoprivrede te utjecaj depopulacije ili neprimjerene izgradnje $\mathrm{u}$ obalnim područjima koji degradiraju kulturni krajolik. $\mathrm{U}$ Konvenciji o europskim krajolicima (koju je supotpisala i Hrvatska 2000.; Narodne novine, 12/2000) istaknuta je obveza potpisnica o »...jačanju svijesti građana, privatnih organizacija i javnih vlasti o vrijednostima krajobraza, njihovoj ulozi i promjenama u njima « (članak 6.) (The European Landscape Convention, 2000). Hrvatska je doduše zakonskom regulativom predvidjela zaštitu krajolika, uz ostalo i posebnom kategorijom značajni krajobraz (Zakon o zaštiti prirode, Narodne novine, 80/2013), a u slučaju Starogradskog polja na otoku Hvaru ostvaren je najviši stupanj zaštite jer je taj kompleks u kojem su očuvani ostaci kulturnoga krajolika oblikovanoga još u antici, u vrijeme grčke kolonizacije, upisan na UNESCO-ovu Listu svjetske baštine 2008. Premda zakonskom zaštitom, barem kako je to predviđeno za zaštićene dijelove prirode i kulturne spomenike, nije moguće obuhvatiti sve otoke, potrebno je spriječiti eskalacije koje već i na vizualnoj razini mijenjaju otočni identitet.

Promjene otočnoga krajolika kvantitativno je moguće pratiti na temelju katastarskih podataka o udjelima pojedinih kategorija upotrebe zemljišta. Nažalost, noviji podaci nisu vjerodostojni jer poljoprivredna proizvodnja zbog koje je, uz ostalo, i ustrojen katastar više nije osnovna gospodarska djelatnost, pa je i interes pojedinaca, ali i cijele društvene zajednice za konstantno aktualiziranje katastarskih podataka oslabio. Suvremene mogućnosti vrednovanja agrarnog prostora s obzirom na njegove prenamjene $\mathrm{u}$ korist turizma i graditeljstva kao i potreba izgradnje preciznoga sustava imovinsko-pravnih odnosa i s njim u vezi poreznoga sustava države postupno pridonose novim katastarskim izmjerama, čime se, doduše vrlo sporo, aktualizira kvantitativni i kartografski prikaz trenutačnoga stanja krajolika. Unatoč tim problemima najnoviji katastarski podaci u usporedbi s onima iz sredine 20. stoljeća te u korelaciji s bitemporalnim parovima fotografija (koje prikazuju isti prostor snimljen u različitim razdobljima; slika 2) mogu poslužiti za kvantitativno i kvalitativno sagledavanje promjena krajolika (tablica 2), najčešće u smislu smanjenja udjela obradivih površina te povećanja površina pod šumom (zapravo makijom i nižim šumama autohtone vegetacije, ali i nekim elementima alohtonog raslinja poput alepskoga i primorskog bora). 
$\frac{1}{2}$

華.

要.

ฮี

ฮृ

F

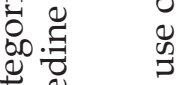

艺

E. Nㅛ 플

$\frac{\pi}{\sqrt{2}} \cdot \frac{\pi}{\sqrt{3}} m$

चี

ฮ $\pi$ व

퓨 유

ช

है

สิ

ส

光

E

क

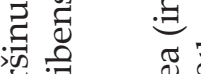

的 ब

ह छ

ซ

हี

雨

กิ ฐ

क ह चु ब

ช

응 홍

चี ซ

ส ส

동

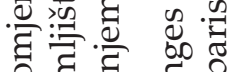

ป స्ञ

iv

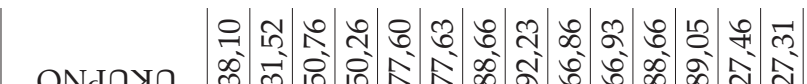

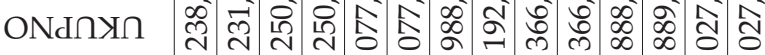

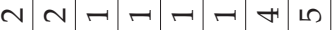

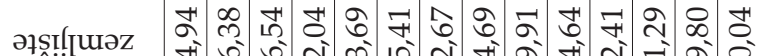

oupo[dan एँ

ษ

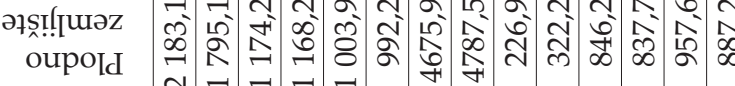

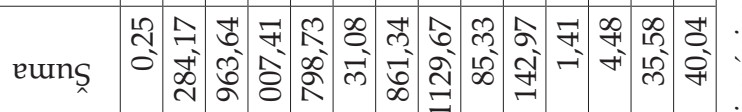

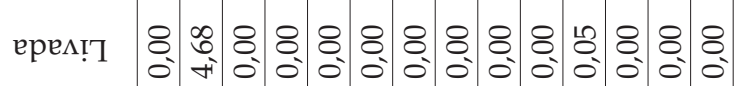

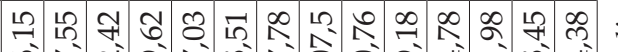

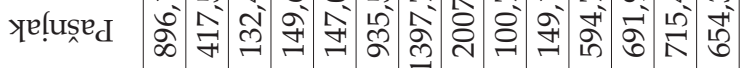

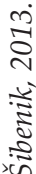

$\frac{\sqrt{2}}{\frac{2}{3}}$

$\stackrel{\Xi}{\vdots}$

$\frac{0}{\frac{0}{2}}$

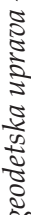

әтsтlüz

osipesqO

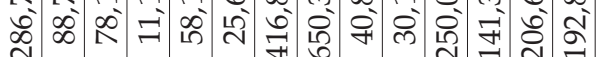

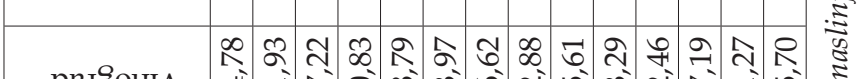

pexolou! $\Lambda$ मी

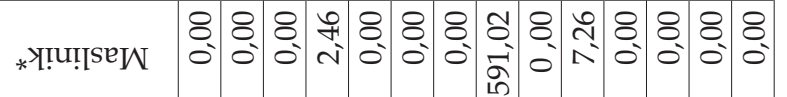

৪ न ले लै

yeluग, $\Lambda$ o

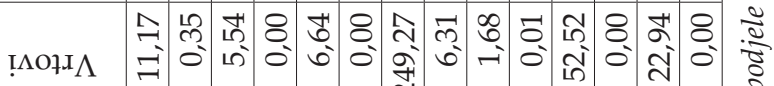

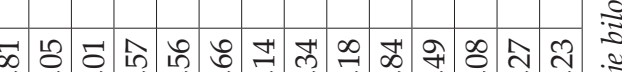

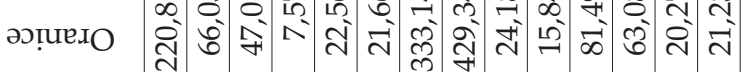

eutpo 芯

芩

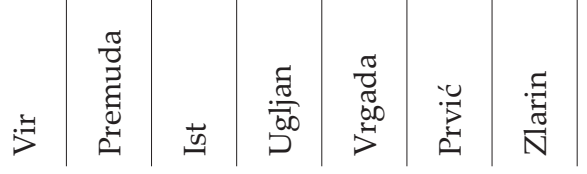


Slika 2: $\quad$ Promjene kulturnoga krajolika na otoku Istu: a) stanje $s$ početka 20. stoljeća (zbirka Z. Šuljka); b) stanje snimljeno 2010. (snimio J. Faričić)

Figure 2. Changes in the cultural landscape on the island of Ist: a) state in the early 20th century (Z. Šuljak collection); b) state recorded in 2010 (photo by J. Faričić)
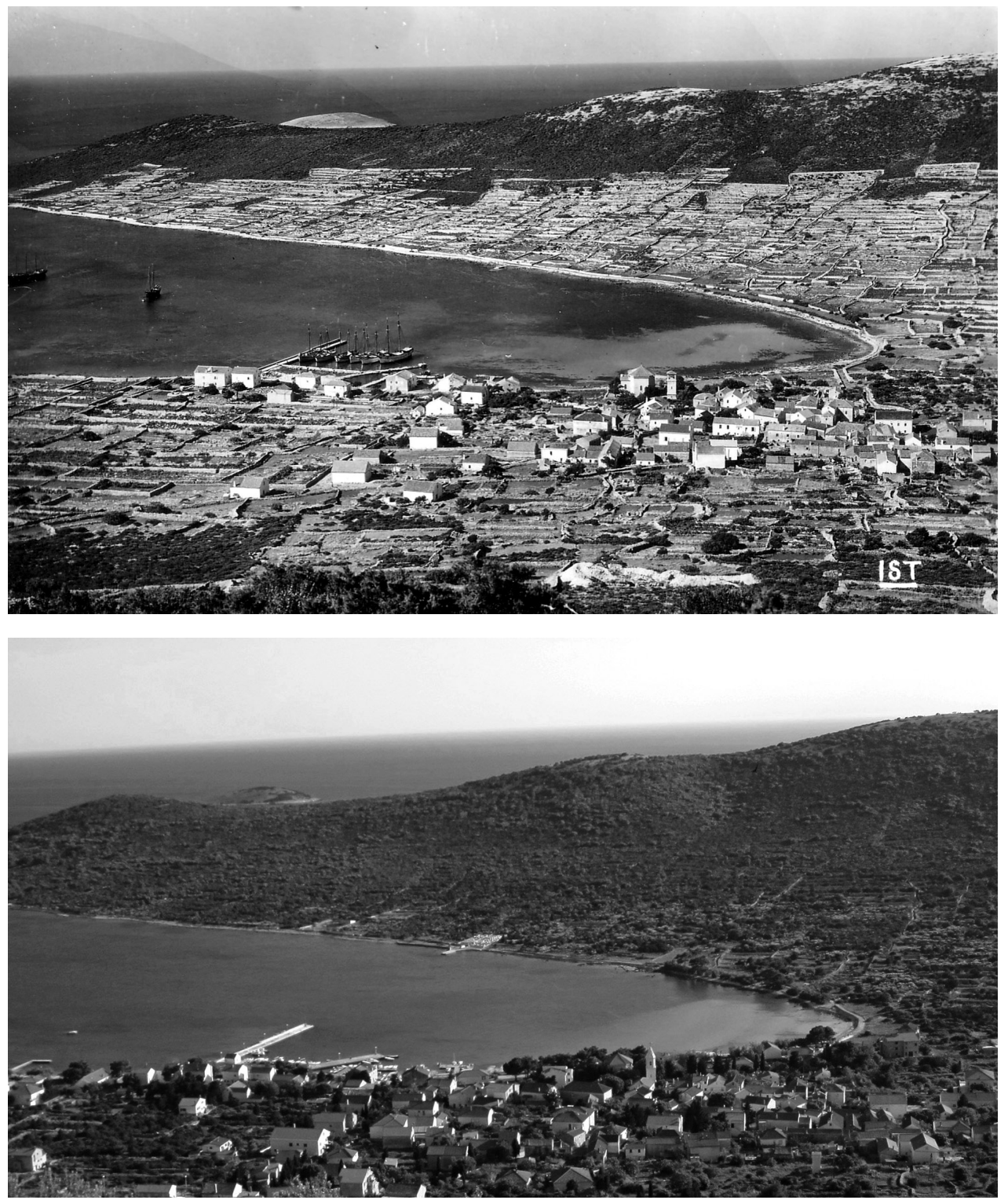
Jezična baština dio je kompleksne kulturne baštine, a odražava razvoj odgovarajuće jezične zajednice na nekom prostoru. Jezik je važni tvorbeni element prostornog identiteta (lokalnoga, regionalnog i nacionalnog). Geografski okvir razvoja jezika umnogome utječe ponajprije na rječnik. Geografska obilježja i geografski procesi na hrvatskim su otocima uvjetovali specifični način vrednovanja i upotrebe otočnoga i pripadajućeg morskog prostora, što se odražavalo i na svakidašnju komunikaciju otočana, koja se temelji na usmenoj i pisanoj jezičnoj komunikaciji. Sukladno tome otočni leksik bogat je geografskim imenima i apelativima vezanim uz prirodu te različite poljoprivredne i pomorske aktivnosti.

Smanjenjem broja stanovnika na otocima se ujedno smanjuje i broj izvornih govornika, tj. korisnika bogatoga lokalnog leksika, koji se, ako nije popisan, postupno gubi. U pojedinim se slučajevima zamjenjuje standardnim jezičnim oblicima, a češće posve nestaje iz govornoga jezika, čime se fond riječi umnogome smanjuje. Stanovništvo koje upotrebljava lokalne toponime te nazive za biljke, životinje, poljoprivredne i pomorske (posebno ribarske) tehnike i alate sve je starije i malobrojnije, a mlađe stanovništvo gubi neposredan kontakt čak i sa svojom privatnom imovinom, koja se zapušta i prepušta prirodnoj sukcesiji biljnoga pokrova. Tradicionalni kulturni krajolik znatno se preobražava, obradive površine zamjenjuju makija te šumarci, dok se atraktivni obalni pojas prenamjenjuje u područje razvoja lučkih djelatnosti, turizma, stanogradnje, a rijetko i industrije (npr. na Krku i Či$\mathrm{ovu}$ ). S prenamjenom površina mijenja se ambijent $\mathrm{u}$ kojem funkcioniraju toponimi. S obzirom na to da na topografskim i pomorskim kartama, čak i onima najkrupnijeg mjerila, brojna geografska imena uopće nisu zabilježena te da je mali broj otoka kvalitetno toponomastički obrađen (to je, zahvaljujući sustavnom djelovanju Centra za jadranska onomastička istraživanja Sveučilišta u Zadru te istaknutih pojedinaca u drugim ustanovama, ponajprije u HAZU-u, učinjeno za petnaestak naseljenih otoka i više desetaka pripadajućih otočića i grebena), sasvim je izgledno da će toponomastički dio otočnoga jezičnog blaga (geografska imena te s njima povezani ktetici i etnici) s posljednjim otočanima nestati. Primjerice terenskim istraživanjem, odnosno anketiranjem starijega otočnog stanovništva otoka Rave (površina $3,62 \mathrm{~km}^{2}$ ) utvrđeno je 212 geografskih imena (Jurić, 2008), a na topografskoj karti u mjerilu 1 : 25.000 (list Veli Iž 469-3-3, Državna geodetska uprava, 1997) zabilježeno je svega četrdeset toponima, na pomorskoj karti u mjerilu $1: 50.000$ (list Sedmovraće, HHI, 2000) zapisana su 24, a na najčešće upotrebljavanoj pomorskoj karti iz edicije male karte Hrvatskoga hidrografskog instituta iz 2009. u mjerilu 1 : 100.000 (list Zadar 013) zabilježeno je samo 
petnaest geografskih imena. Dakle na topografskoj karti u mjerilu $1: 25.000$ zabilježeno je 18,9\% od toponima koji se i danas upotrebljavaju na Ravi, na pomorskoj karti u mjerilu 1 : 50.000 svega 11,3\%, a na pomorskoj karti u mjerilu $1: 100.000$, koju pomorci (ribari, nautičari i dr.) najčešće upotrebljavaju, samo 7,0\% ravskih toponima. Na otoku Ugljanu (površina 51,05 $\mathrm{km}^{2}$ ) istraživanjem V. Skračića i suradnika iz 2007. utvrđena su 1133 toponima, na topografskoj karti u mjerilu $1: 25.000$ (pet listova: Rivanjski kanal 469-3-1, Nin 469-3-2, Veli Iž 469-3-3, Zadar /zapad/ 469-3-4 i Zadar/istok/ 469-4-3, Državna geodetska uprava, 1997) zabilježeno je 228 toponima, a na pomorskoj karti u mjerilu 1 : 100.000 (list Zadar 013, HHI, 2009) zabilježena su 63 toponima. To znači da je na topografskoj karti u mjerilu $1: 25.000$ zabilježeno $20,1 \%$ ugljanskih toponima, a na pomorskoj karti u mjerilu 1 : 100.000 svega 5,6\% toponima otoka Ugljana. Iz toga proizlazi da alohtoni korisnici otočnog prostora na raspolaganju imaju najviše petinu korpusa otočne toponimije (Faričić, 2011).

Slično je i s brojnim apelativima po kojima se razlikuju lokalni otočni govori (na većim se otocima po apelativima razlikuju i susjedna naselja). Brojne opće imenice nestaju, nekima se mijenja izgovor, prilagođavaju se jezičnom standardu ili posve nestaju. Tako zapravo čakavsko narječje hrvatskoga jezika (usp. Lisac, 2009) gubi svoju raznolikost i poprima uniformnost, a s time gubi i brojne elemente svoje izvornosti. Primjerice spontanim nestajanjem pojedinih ribarskih tehnika uzrokovanim smanjenjem broja i starenjem otočnih ribara, kao i zakonskim zabranama (pa i onima koje su provedene u sklopu prilagodbe hrvatskoga ribarskog zakonodavstva pravnoj stečevini Europske unije; usp. Zakon o morskom ribarstvu, Narodne novine, 81/2013) više se ne upotrebljavaju brojni stari ribarski alati ni vještine njihove izrade i popravka (npr. izrada vrša te izrada i krpanje mreža) niti se love različite riblje vrste. Zapravo, ribarstvo i marikultura usredotočuju se na profesionalni izlov ili uzgoj morskih organizama koji imaju najbolji ili najskuplji plasman na tržište i prilagođava se sve ujednačenijoj gastronomskoj ponudi u hrvatskim obalnim regijama. Tako od više od stotinu konzumnih vrsta jadranske ribe jelovnici u primorskim ugostiteljskim objektima uglavnom nude svega njih desetak (uglavnom kvalitetne bijele ili jeftine plave ribe) pripremljenih na tri najčešća načina (pečenje, kuhanje i prženje). Dakle mnoge riblje vrste više se ne love (što se pozitivno odražava na očuvanje bioraznolikosti) i ne pripremaju se na tradicionalne načine (osim brojnih oblika termičke obrade gotovo su posve nestali soljenje, dimljenje i sušenje ribe). Logična je posljedica da se rječnik jadranske faune i s njom povezanih ribarskih tehnika i običaja te tradicionalnih jela 
umnogome smanjuje, a upravo je to jedan od najbogatijih leksika na hrvatskim otocima (Vinja, 1986; Božanić, 2011; Vuletić, 2013).

U pogledu otočne poljoprivrede i ribarstva nije samo jezična baština izložena nestajanju nego i brojne tehnike i vještine. Naravno, to nije samo posljedica depopulacije već i primjene suvremenih i sve dostupnijih (fizički i financijski) alata i inovacija u poljoprivrednoj proizvodnji i ribarstvu. Modernizacija tih gospodarskih djelatnosti pozitivna je u smislu olakšavanja fizičkog rada, primjene kvalitetnijega i trajnijeg alata i sl. No uz ta poboljšanja dolazi i do nestanka vještina kojima su upotrebom prirodnih materijala stoljećima oblikovani korisni i estetski vrijedni proizvodi poput sprta - košara pletenih od pruća (najčešće od mirte). Sprte (i druge pletene proizvode poput vrša) zna izrađivati sve manji broj otočana (primjerice od brojnih otočana koji su to činili na otoku Ravi u zadarskom arhipelagu, nadaleko poznatoj po izradi sprta i vrša, danas tu vještinu poznaju i primjenjuju svega tri vrlo stare osobe; Lulić Štorić, 2008), a zapuštanje ruralnog prostora pridonosi intenzivnom rastu makije, $u$ kojoj grmovi mirte više nemaju pravilne forme s dugim i vitkim granama, nego je rast nadzemnog dijela te biljne vrste prilagođen tijesnim uvjetima u novom staništu, pa su grane nepravilna oblika. Sprte su zamijenjene plastičnim posudama i košarama, a pletene vrše metalnima i plastičnima. Slično je is tradicionalnom proizvodnjom zemljanog posuđa u Velom Ižu na otoku Ižu. Zemljane čripnje (peke) i lopiži (zdjele) izrađivalo je mnogo Ižana (Oštrić, 1978; Cvitanović, 1989), a danas ih u Velom Ižu izrađuje samo jedna osoba. Odjel za etnologiju i kulturnu antropologiju Sveučilišta u Zadru u suradnji s Etnološkim odjelom Narodnog muzeja Zadar planira organiziranje ljetne škole na kojoj će se proučavati povijest i etnološka obilježja te tradicionalne proizvodnje, a u praktičnom dijelu organizirat će se radionica za izradu zemljanog posuđa.

Analogna i još značajnija promjena događa se u brodogradnji. Male višenamjenske brodice (batele, pasare, gajete i guci) rijetko se grade od drva jer je brodograditelja malo (još je uvijek vitalna drvena brodogradnja u Betini na Murteru, u Sumartinu na Braču, a u manjoj mjeri i u Barbatu na Rabu, u Korčuli i na nekim drugim otocima), a i narudžbi je sve manje. Naime moderni korisnici otočnih i morskih resursa nemaju više vremena za pomno i vremenski zahtjevno održavanje drvenog broda, nego se okreću različitim modelima plastičnih brodica sa sve jačim izvanbrodskim motorima. $\mathrm{Na}$ plastične brodice prelazi i starije stanovništvo jer više nije sposobno svake godine barem tjedan dana obavljati pedantne radove održavanja i zaštite drvene brodice. Posljedica je nestanak drvene brodogradnje i vještinâ popravljanja i održavanja broda te promjena fizionomije otočnih lučica, u ko- 
jima plastične brodice postupno istiskuju drvene. Primjerice evidencijom brodica na Ravi 2008. zabilježene su 44 drvene i 40 plastičnih brodica (Lončarić, 2008), na Vrgadi su 2009. popisane 73 drvene i 44 plastične brodice (Faričić i Magaš, 2009), a na Istu je 2010. zabilježeno 70 drvenih i 52 plastične brodice (Segarić, 2010). Na tim su otocima gotovo svi drveni brodovi stariji od dvadeset godina, a sve brodice nabavljene u posljednja dva desetljeća izrađene su od stakloplastike. »Plastificiranje« otočnih brodica rezultat je tehnoloških inovacija i pojednostavljenja održavanja tih višenamjenskih plovila, a posjedovanje i održavanje drvenih brodova postali su svojevrstan luksuz s obzirom na utrošak novca i vremena, slično kao i obnova ili održavanje tradicionalnoga graditeljstva s primjenom materijala koji zahtijevaju neprestanu skrb (poput drvene vanjske stolarije, kamenih pročelja i sl.), a da se pritom ne jamče suvremeni zahtjevi u pogledu toplinske i zvučne izolacije te hidroizolacije. Stoga je financijski krhkim otočnim kućanstvima potrebna pomoć lokalnih, županijskih i državnih vlasti žele li se očuvati ti tradicionalni sadržaji na otocima. U tom smislu kao dobar primjer može poslužiti revitalizacija rapske lađe, tradicionalne brodice namijenjene ribolovu i prijevozu do zemljišnih posjeda. Nakon znanstvenog istraživanja prošlosti rapske lađe, na Tehničkom fakultetu Sveučilišta u Rijeci obavljena je tehnička analiza, a zatim je oblikovan model po kojemu se počelo izrađivati tu gotovo zaboravljenu brodicu. Rekonstrukcija i izrada rapske lađe bile su moguće na samom Rabu jer je na tom otoku još uvijek razvijena mala brodogradnja (Andrić, 2012).

\section{ZAKLJUČAK}

Depopulacija kao ključni demografski proces na većini hrvatskih otoka umnogome utječe na kulturnu baštinu. Smanjenje broja stanovnika ujedno znači smanjenje broja nositelja tradicionalne kulture, odnosno onih koji svojim načinom života i vrednovanja prostora grade otočni identitet. Iščezavanju su najizloženiji različiti elementi nematerijalne kulturne baštine poput jezika, običajâ i tradicionalnih vještina povezanih sa svakidašnjim životom te prevladavajuće gospodarske aktivnosti otočana. Budući da je preostalo otočno stanovništvo pretežito starije životne dobi i da je vrlo malo mladog stanovništva, postupno se smanjuje kapacitet međugeneracijskog prijenosa tradicionalne kulture. Usto modernizacija različitih aspekata svakidašnjeg života i gospodarskih aktivnosti pridonosi postupnom smanjenju, a zatim i nestanku potrebe za pojedinim elementima tradicionalne kulture (primjerice upotreba lako dostupnih i jeftinih plastičnih posuda za plodove maslina 
tijekom berbe nadomješta košare pletene od pruća mirte, pa takve košare više ne treba izrađivati).

S obzirom na intenzitet negativnih demografskih procesa moguće je pretpostaviti da su iščezavanju kulturne baštine najizloženiji mali i od kopna udaljeni otoci. Na njima živi mali broj stanovnika, koje u pravilu obilježava krajnje duboka starost. To su ujedno otoci na kojima uglavnom ne postoje institucionalizirani oblici kulturnih aktivnosti (u muzejima, knjižnicama, galerijama, kulturnim udrugama i dr.), kakvih je mnogo na većim i u demografskom pogledu stabilnijim otocima.

Da bi se spriječilo ili barem usporilo posvemašnje uniformiranje koje prijeti pretvaranjem hrvatskih otoka u bezlično sociokulturno tkivo, predlaže se »muzeološki« pristup otocima. Naime otoke je moguće promatrati kao muzeje na otvorenome, pa bi im stoga trebalo pristupiti tako da se kulturna baština otoka inventarizira, istraži, zaštiti i predstavi javnosti, posebno u obliku turističkog vrednovanja otočnog prostora. U tom smislu akademska zajednica ima veliku odgovornost, koju treba dijeliti s mjerodavnim ustanovama i tijelima na svim razinama odlučivanja, s udrugama civilnoga društva te, naravno, sa samim otočanima. Takav »frontalni« pristup otocima, nasuprot dosadašnjemu parcijalnom i pojedinačnom, zacijelo bi mogao rezultirati primjerenim vrednovanjem otočne kulturne baštine. No nije realno očekivati čudesne rezultate jer je na otocima stanovnika sve manje, sve su stariji i sve manje permanentno gospodare svim raspoloživim otočnim resursima. Istodobno je sve više stanovnika koji otoke nastanjuju povremeno (ljeti i vikendima) i koji ih, ponajprije njihov uski priobalni dio, doživljavaju kao prostor odmora i rekreacije. Takvi će zacijelo prevladati na mnogim otocima, a krajnji je trenutak da ih se kulturološki pokuša makar djelomično »inzularizirati«.

\section{LITERATURA}

Andrić, J. (2012). Rapska lađa, u: J. Andrić i R. Lončarić (ur.). Rapski zbornik II. Rab Zadar: Matica hrvatska-Rab - Sveučilište u Zadru, 383-403.

Andrić, J. i Lončarić, R. (ur.) (2013). Rapski zbornik II. Rab - Zadar: Matica hrvatska-Rab - Sveučilište u Zadru.

Arianoutsou, M. (2001). Landscape changes in Mediterranean ecosystems of Greece: implementations for fire and biodiversity issues, Journal of Mediterranean Ecology, 2: 165-178.

Atkinson, D. (2008). Baština, u: D. Atkinson i dr. (ur.). Kulturna geografija: kritički rječnik ključnih pojmova. Zagreb: Disput, 189-199. 
Babić, D., Lajić, I. i Podgorelec, S. (2004). Otoci dviju generacija. Zagreb: Institut za migracije i narodnosti.

Božanić, J. (2011). Lingua halieutica: ribarski jezik Komiže. Split: Književni krug.

Chevalier, J. i Gheerbrant, A. (2007). Rječnik simbola: mitovi, snovi, običaji, geste, oblici, likovi, boje, brojevi. Zagreb: Kulturni informativni centar - Jesenski i Turk.

Convention concerning the Protection of the World Cultural and Natural Heritage (1972). Paris: UNESCO.

Convention for the Safeguarding of Intangible Cultural Heritage (2003). Paris: UNESCO.

Cvitanović, A. (1989). Otok Iž. Veli Iž: Mjesna zajednica.

Čizmić, I. (1974-1975). O iseljavanju iz Hrvatske u razdoblju 1880.-1914., Historijski zbornik, 27-28: 27-47.

Čuka, A. (2013). Razvoj poljoprivrede i promjene krajolika sjeverozapadnog dijela Dugoga otoka, u: A. Uglešić i J. Faričić (ur.). Veli Rat. Zadar: Sveučilište u Zadru, 541-568.

Duplančić Leder, T., Ujević, T. i Čala, M. (2004). Coastline lengths and areas of islands in the Croatian part of Adriatic Sea determined from the topographic maps at the scale of 1:25.000, Geoadria, 9 (1): 5-32.

The European Landscape Convention. Firenze: Council of Europe.

Faričić, J. (2007). Sastavnice kulturne baštine hrvatskoga otočnog prostora i mogućnosti njihovoga društveno-gospodarskog vrednovanja, u: A. Filipčić (ur.). IV. hrvatski geografski kongres: Geografsko vrednovanje prostornih resursa. Zagreb: Hrvatsko geografsko društvo, 73-94.

Faričić, J. (ur.) (2008). Otok Rava. Zadar: Sveučilište u Zadru.

Faričić, J. (ur.) (2010). Otoci Ist i Škarda. Zadar: Sveučilište u Zadru.

Faričić, J. (2011). Neki geografski aspekti proučavanja toponima, u: V. Skračić i J. Faričić (ur.). Geografska imena: zbornik radova s Prvoga nacionalnog znanstvenog savjetovanja o geografskim imenima. Zadar: Sveučilište u Zadru - Hrvatsko geografsko društvo, 51-66.

Faričić, J. (2012). Geografija sjevernodalmatinskih otoka. Zagreb - Zadar: Školska knjigaSveučilište u Zadru.

Faričić, J., Čuka, A. i Colić, V. (2010). Poljoprivreda i razvoj ruralnoga krajolika Ista i Škarde, u: J. Faričić (ur.). Otoci Ist i Škarda. Zadar: Sveučilište u Zadru, 573-598.

Faričić, J., Graovac, V. i Čuka, A. (2010). Mali hrvatski otoci-radno-rezidencijalni prostor i/ili prostor odmora i rekreacije, Geoadria, 15 (1): 145-185.

Faričić, J. i Magaš, D. (2009). Geografski ambijent oblikovanja i korištenja toponima na otoku Vrgadi, u: V. Skračić (ur.). Toponimija otoka Vrgade. Zadar: Centar za onomastička istraživanja Sveučilišta u Zadru, 11-59.

Fernandez Ales, R., Martin A., Ortega, F. i Ales, E. E. (1992). Recent changes in landscape structure and function in a mediterranean region of SW Spain (1950-1984), Landscape Ecology, 7 (1): 3-18.

Gams, I., Nicod, J., Sauro, M., Julian, E. i Anthony, U. (1993). Environmental change and human impacts on the Mediterranean karst of France, Italy and the Dinaric Region, u: P. W. Williams (ur.). Karst terrains: environmental changes and human impact. Cremlingen: CatenaVerlag, 59-83.

Graovac, V. (2004). Islands on the verge of extinction - the example of Zadar Islands, Croatia, Geoadria, 9 (2): 183-210. 
Graovac, V. (2009). Demogeografske osnove razvoja zadarske regije (doktorska disertacija). Zagreb: Prirodoslovno-matematički fakultet Sveučilišta u Zagrebu.

Gredičak, T. (2009). Kulturna baština i gospodarski razvitak Republike Hrvatske, Ekonomski pregled, 60 (3-4): 196-218.

Ivan Pavao II. (1991). Centesimus Annus. Vaticano: Libreria Editrice Vaticana.

Jackson, P. (1994). Maps of Meaning: An Introduction to Cultural Geography. New York: Routledge.

Jelinčić, D. A. (2006). Turizam vs. Identitet. Globalizacija i tradicija, Etnološka istraživanja, 11 (1): 161-183.

Jović Mazalin, S. (2014). Preobrazba kulturnog krajolika Elafita (doktorska disertacija). Zadar: Sveučilište u Zadru.

Jurić, A. (2008). Suvremena ravska toponimija: (izvješće s ponovljenoga terenskog istraživanja), u: J. Faričić (ur.). Otok Rava. Zadar: Sveučilište u Zadru, 123-146.

Kale, E. (ur.) (1994). Žirajski libar: zbornik radova o otoku Žirju. Žirje - Šibenik: Nakladno povjerenstvo Žirajskog libra - Muzej grada Šibenika.

Kizos, T. i Koulouri, M. (2006). Agricultural landscape dynamics in the Mediterranean: Lesvos (Greece) case study using evidence from the last three centuries, Environmental Science and Policy, 9: 330-342.

Klarić, V. i Vince-Pallua, J. (2006). Spirit of the Space - Challenges of its Contemporary Use in Cultural Tourism, Etnološka tribina, 36: 207-222.

Lajić, I. (1992). Stanovništvo dalmatinskih otoka: povijesne i suvremene značajke depopulacije. Zagreb: Consilium - Institut za migracije i narodnosti.

Lajić, I. (1997). Suvremena demografska problematika jadranskih otoka, u: N. Starc, M. Kaštelan-Macan i S. Ćurlin (ur.). Nacionalni program razvitka otoka. Zagreb: Ministarstvo obnove i razvitka, 13-32.

Lajić, I. (2000). Demografska revitalizacija i zaštita kulturne baštine: primjer Županije primorsko-goranske, Migracijske teme, 16 (3): 261-269.

Lajić, I. (2006). Kvarnerski otoci - demografski razvoj i povijesne mijene. Zagreb: Institut za migracije i narodnosti.

Lajić, I. i Mišetić, R. (2006). Otočni logaritam: aktualno stanje i suvremeni demografski procesi na Jadranskim otocima. Zagreb: Institut za migracije i narodnosti - Ministarstvo mora, turizma, prometa i razvitka.

Lisac, J. (2009). Hrvatska dijalektologija. Sv. 2: Čakavsko narječje. Zagreb: Golden marketing - Tehnička knjiga.

Lončarić, R. (2008). Ribarstvo otoka Rave, u: Faričić, J. (ur.). Otok Rava. Zadar: Sveučilište u Zadru, 515-529.

Lulić Štorić, J. (2008). Tradicijska kultura otoka Rave i njezina suvremena primjena, u: J. Faričić (ur.). Otok Rava. Zadar: Sveučilište u Zadru, 427-438.

Magaš, D. (2013). Geografija Hrvatske. Samobor - Zadar: Meridijani - Sveučilište u Zadru.

Mužinić, J. i Purger, J. (ur.) (2013). Otok Silba. Zadar: Sveučilište u Zadru.

Nejašmić, I. (1991). Depopulacija u Hrvatskoj: korijeni, stanje i izgledi. Zagreb: Globus i Institut za migracije i narodnosti.

Nejašmić, I. (2005). Demogeografija: stanovništvo u prostornim odnosima i procesima. Zagreb: Školska knjiga. 
Nejašmić, I. (2008). Stanovništvo Hrvatske - demogeografske studije i analize. Zagreb: Hrvatsko geografsko društvo.

Nejašmić, I. (2013). Demografsko starenje na hrvatskim otocima, Migracijske i etničke teme, 29 (2): 141-168.

Oštrić, O. (1978). Narodno lončarstvo. Zadar: Narodni muzej Zadar.

Pančić Kombol, T. (2006). Kulturno naslijeđe i turizam, Radovi Zavoda za znanstveni radVaraždin, 16-17: 211-226.

Pažanin, I. (ur.) (2000). Zbornik otoka Drvenika, sv. 1-2. Drvenik: Župa Sv. Jurja Mučenika.

Pinto-Correia, T. i Vos, W. (2004). Multifunctionality in Mediterranean Landscapes past and future, u: R. Jongman (ur.). The New Dimensions of the European Landscape, Wageningen: Springer, 135-164.

Pungetti, G. (1995). Anthropological approach to agricultural landscape history in Sardinia, Landscape and Urban Planning, 31: 47-56.

Radman, Z. (ur.) (2012). Otok Šolta. Grohote: Općina Šolta.

Segarić, R. (2010). Ribarstvo otoka Ista i Škarde, u: J. Faričić (ur.). Otoci Ist i Škarda. Zadar: Sveučilište u Zadru, 691-733.

Skračić, V. (1997). Baština, kultura, obrazovanje, u: N. Starc, M. Kaštelan-Macan i S. Curlin (ur.). Nacionalni program razvitka otoka. Zagreb: Ministarstvo obnove i razvitka, 331-349.

Skračić, V. (2008). Mali otoci - prepoznatljiv znak hrvatske posebnosti na Mediteranu, u: Faričić, J. (ur.). Otok Rava. Zadar: Sveučilište u Zadru, 43-50.

Skračić, V. (2013). Otočani na malim otocima danas, Migracijske i etničke teme, 29 (2): 277-293.

Skračić, V. (ur.) (2006). Toponimija otoka Pašmana. Zadar: Centar za jadranska onomastička istraživanja Sveučilišta u Zadru.

Skračić, V. (ur.) (2007). Toponimija otoka Ugljana. Zadar: Centar za jadranska onomastička istraživanja Sveučilišta u Zadru.

Skračić, V. (ur.) (2009). Toponimija otoka Vrgade. Zadar: Centar za jadranska onomastička istraživanja Sveučilišta u Zadru.

Skračić, V. (ur.) (2010). Toponimija otoka Murtera. Zadar: Centar za jadranska onomastička istraživanja Sveučilišta u Zadru.

Skračić, V. (ur.) (2011). Toponimija otoka Paga. Zadar: Centar za jadranska onomastička istraživanja Sveučilišta u Zadru.

Skračić, V. (ur.) (2013). Toponimija kornatskog otočja. Zadar: Centar za jadranska onomastička istraživanja Sveučilišta u Zadru.

Šakaja, L. (1997). Kultura kao objekt geografskog proučavanja, Društvena istraživanja, 7 (35): 461-484.

Šakaja, L. (1999). Kultura i prostor: prostorna organizacija kulturnih djelatnosti u Hrvatskoj. Zagreb: Hrvatska sveučilišna naklada.

Uglešić, A. i Faričić, J. (ur.) (2013). Veli Rat. Zadar: Sveučilište u Zadru.

UNESCO Universal Declaration on Cultural Diversity (2001). Paris.

Vinja, V. (1986). Jadranska fauna: etimologija i struktura naziva, sv. 1-2. Zagreb - Split: JAZU - Logos. 
Vrtiprah, V. (2006). Kulturni resursi kao činitelj turističke ponude u 21. stoljeću, Ekonomska misao i praksa, 15 (2): 279-296.

Vuković, M. (2011). Pogled na međuodnos baštine, kulture i identiteta, Arhivski vjesnik, 54: 97-113.

Vuletić, N. (2013). Talasozoonimija sjeverozapadnog dijela Dugoga otoka, u: A. Uglešići i J. Faričić (ur.). Veli Rat. Zadar: Sveučilište u Zadru, 735-752.

Zakon o morskom ribarstvu, Narodne novine, 81/2013.

Zakon o potvrđivanju Konvencije o Europskim krajobrazima, Narodne novine, 12/2002.

Zakon o zaštiti prirode, Narodne novine, 80/2013.

\section{IZVORI}

Naselja i stanovništvo Republike Hrvatske 1857.-2001., CD ROM, Državni zavod za statistiku, Zagreb, 2005.

Popis stanovništva, kućanstava i stanova 2011. godine, Državni zavod za statistiku, Zagreb, www.dzs.hr

Statistički ljetopis Republike Hrvatske 2010., Državni zavod za statistiku, Zagreb, www. dzs.hr

Statistički ljetopis Republike Hrvatske 2013., Državni zavod za statistiku, Zagreb, www. dzs.hr 


\title{
Influence of Depopulation on Cultural Heritage of Croatian Islands
}

\author{
Josip Faričić, Lena Mirošević, Vera Graovac Matassi
}

\begin{abstract}
SUMMARY
The paper discusses the influence of depopulation on cultural heritage of Croatian islands. Comprehensive analysis of relevant statistical data and the existing literature, along with archival and field researches indicate that depopulation is the most important demographic process on most of the Croatian Islands. As the number of insular population decreases, the insular identity gradually disappears, along with different elements of tangible and intangible cultural heritage. Since the number of young population on the islands is decreasing (and young population is the foundation of biological vitality and economic sustainability) and that cohort is largely affected by tertiarization of economy and modernization of the entire life, there are fewer possibilities for intergenerational transfer of traditional insular culture. This particularly refers to intangible cultural heritage, such as language (rich vocabulary, including a large number of toponyms), music (Glagolitic folk singing, etc.), skills (related to making fishing and agricultural tools, etc.), customs, etc. However, it is important to note that in modern valorization of insular space, particularly through tourist activities, certain elements of cultural heritage are mostly perceived as cultural fossils deserving special interest, although precisely this cultural tourism can contribute to the presentation and protection as well to optimal economic use of the island cultural heritage.
\end{abstract}

KEY WORDS: Croatian islands, population, depopulation, cultural heritage 